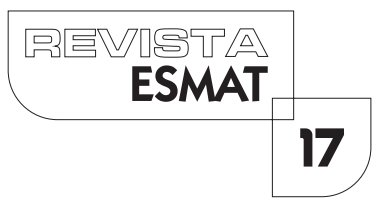

\title{
A PROVA CIVIL NO BRASIL E EM PORTUGAL À LUZ DOS PRINCÍPIOS CONSTITUCIONAIS DO DEVIDO PROCESSO LEGAL, DO CONTRADITÓRIO E DA ISONOMIA
}

\author{
EVIDENCE IN LAWSUITS IN BRAZIL AND PORTUGAL CONSIDERING THE \\ CONSTITUTIONAL PRINCIPLES OF DUE PROCESS, ADVERSARIAL SYSTEM AND \\ EQUALITY OF PARTIES
}

José Eustáquio de Melo Júnior

Juiz de Direito do Tribunal de Justiça do Estado do Tocantins. Mestre em Ciências Jurídicas, pela Faculdade de Direito da Universidade de Lisboa. Formador cadastrado na Escola Nacional de Formação e Aperfeiçoamento de Magistrados (ENFAM), em Brasília, Distrito Federal. Coordenador e professor do curso de pós-graduação "lato sensu" em Direito Privado da Escola Superior da Magistratura Tocantinense (ESMAT). E-mail: jrjeustaquio@gmail.com

Gustavo Paschoal Teixeira de Castro Oliveira

Doutor em Direito das Relações Internacionais, pelo Centro Universitário de Brasília (UniCeub). Mestre em Direito Constituição e Processo, pela Universidade de Ribeirão Preto (UNAERP). Especialista em Direito Civil e Direito Processual Civil, pela Universidade de Franca (UNIFRAN). Docente na Universidade Federal do Tocantins (UFT) e no Centro Universitário Luterano de Palmas (CEULP/ULBRA). Diretor Financeiro da Escola Superior de Advocacia $O A B$, Seccional Tocantins. Membro da Comissão de Direito Ambiental OAB, Seccional Tocantins. Advogado.

\section{RESUMO}

presente trabalho aborda a prova civil, nos ordenamentos jurídicos brasileiro e português, a partir do enfoque constitucional. Objetiva analisar os princípios do devido processo legal, do contraditório e da isonomia como fundamentos para assegurar a garantia da tutela jurisdicional adequada e efetiva no processo civil a partir da dilação probatória. Utilizando o método dedutivo, é possível compreender como a prova civil caracteriza-se como meio de acesso à justiça.

PALAVRAS-CHAVE: Processo. Prova. Civil. Princípios. Constituição.

\section{ABSTRACT}

This paper addresses the evidence in lawsuits in both Brazilian and Portuguese legal systems, under a constitutional perspective. It analyzes the essential principles of due process, adversarial system and equality of parties to ensure adequate and effective court provisions in lawsuits based on the production of evidences. Through the deductive method, it is possible to understand how the evidence in lawsuits is characterized as a means of access to the judiciary. 
KEYWORDS: Lawsuit. Evidence. Principles. Constitution.

\section{NOÇÕES INTRODUTÓRIAS}

O estudo dirige-se à análise do direito de a parte produzir prova, essencialmente se existem expressamente normas constitucionais no Brasil e em Portugal consagrando essa possibilidade ou se essa autorização encontra-se implícita nesses ordenamentos jurídicos e quais seriam os fundamentos desse direito num caso ou no outro.

A primeira questão que se coloca é saber se a parte tem o direito ou o poder de produzir proval. Essa distinção de plano pode parecer sem propósito, entretanto, assume relevo quando se busca o parâmetro do direito ou do poder à prova a partir de uma base constitucional.

Carnelutti (2000a) assevera a respeito do poder, expressão subjetiva do mandato, que se trata da possibilidade de mandar (para a composição de conflito de interesses) e que se distancia do direito subjetivo, o qual deve ser entendido como a possibilidade de se valer do mandato. Segundo o autor, o ponto comum entre poder e direito subjetivo encontra-se no fato de que ambos são atributos da vontade, sendo que o poder significa domínio da vontade alheia; o direito, domínio da própria vontade.

Micheli (1970), ao analisar os sujeitos do processo, sustenta que a parte dispõe de poder jurídico, dentre os quais o de peticionar a produção de prova, dirigido à prática de atos processuais, e não seria exercido contra o juiz ou a outra parte, motivo pelo qual chamou de poder instrumental da parte. Entretanto, para o autor, esse poder seria suficiente para implicar sujeição da contraparte e do juiz, de modo que estes não poderiam se opor ao exercício desse poder que, uma vez não exercido, não ensejaria nenhuma sanção à parte que não optou por não exercitá-lo. Por essas razões, para o autor, ter-se-ia em conta um poder-carga ou poder-ônus.

Goldschmidt (2003a) sustenta, porém, que as partes são sujeitos de direitos e deveres processuais, portanto, não admite a possibilidade de serem detentoras de poder. De acordo com o autor, os direitos processuais são as expectativas, possibilidades e liberações de um ônus processual.

Aroca (20 I I) afirma que o direito à prova é subjetivo de conteúdo processual e fundamental, sem prejuízo de tratar-se de um direito de configuração legal.

Melhor é empregar o termo direito, e não poder, primeiro porque não se admite o reconhecimento de poder às partes pela Constituição Federal em face da relação processual civil, seja no Brasil ou em Portugal, mas apenas de direitos, e essa posição se fundamenta de plano na inexistência de qualquer norma constitucional nesse sen-

Não interessa a este estudo distinguir direitos e garantias. A Constituição Federal brasileira não adotou nenhum critério de distinção entre ambos, tanto que em seu Título II enunciou "Dos direitos e garantias fundamentais", sendo que no Capítulo I desse Título trouxe a rubrica "Dos direitos e deveres individuais e coletivos" não mencionando as garantias, apesar de boa parte de esse capítulo constituir-se de garantias, como os incisos $X X X V$ a $L X X V I I I$ do art. $5^{\circ}$. 
tido. Para Dinamarco ( 198 I), essa omissão não pareceu esquecimento do legislador constituinte, mas teve uma razão de ser, porque a Constituição no campo da jurisdição atribuiu o exercício do poder ao Estado, por meio do julgador.

E ainda que essa ideia simples, baseada numa interpretação gramatical, não seja suficiente para demonstrar que se trata de direito, e não de poder, existem outros fundamentos que amparam essa tese.

Sustenta-se que se fosse poder implicaria dever para o seu detentor, da mesma maneira que ocorre com o juiz, investido do poder estatal que segue acompanhado de inúmeros deveres, como, por exemplo, o dever de sentenciar, cujo incumprimento pode ensejar uma sanção, mas a parte não tem o dever de produzir prova, tem apenas o ônus processual de produzi-la, sob pena de suportar as consequências de sua própria inatividade, o que implica afastar a noção de poder de a parte produzir prova. Assim, de acordo com Goldschmidt (2003a), a inatividade no processo caracteriza-se como o fato de não se desembaraçar de um ônus processual.

Ademais, nessa mesma linha de raciocínio, esse poder seria irrenunciável porque derivado da manifestação soberana da norma jurídica, mas o Código de Processo Civil, (CPC), de 1973 admite a possibilidade em certas situações de as partes estabelecerem a maneira como será distribuído o ônus da prova². Ocorre, porém, que, com base no princípio dispositivo, os direitos processuais costumam ser renunciáveis, conforme lição de Goldschmidt (2003b). Nesse passo, como o exercício desse "poder" ocorreria por meio do ônus da prova, a distribuição do ônus da prova de maneira diversa daquela prevista na lei, por disposição das próprias partes, poderia significar a renúncia ao próprio "poder" a que fariam jus, o que não se pode admitir.

Também o art. 50, inciso XXXV, da Constituição Federal, de 1988, consagrou expressamente o direito de ação com a seguinte redação: "a lei não excluirá da apreciação do Poder Judiciário lesão ou ameaça a direito”. Alinhado à doutrina de Carnelutti (2000b) e de Marques (2000), defende-se que se trata de direito público e subjetivo de ação, e o direito de produzir prova, nesse sentido, que decorre intrinsecamente do primeiro, não pode se sobrepor a si mesmo, ou seja, não é admissível logicamente que exista um direito de ação assegurado expressamente pela Constituição Federal e um poder de a parte produzir prova não previsto naquela norma.

Por fim, não se admite a ideia de sujeição do juiz ou da contraparte por ocasião

2 Conforme art. 333, parágrafo único, do Código de Processo Civil, de 1973: Parágrafo único. É nula a convenção que distribui de maneira diversa o ônus da prova quando: I - recair sobre direito indisponível da parte; II - tornar excessivamente difícil a uma parte o exercício do direito. No Código de Processo Civil, de 2015, a norma encontra-se no $\S 3^{\circ}$ do art. 373: § 30 A distribuição diversa do ônus da prova também pode ocorrer por convenção das partes, salvo quando: I - recair sobre direito indisponível da parte; II - tornar excessivamente difícil a uma parte o exercício do direito. 
do exercício de a parte produzir prova, pois, de um lado, o juiz poderá indeferir as provas inúteis ou protelatórias requeridas pela parte; por outro, a contraparte tem a faculdade de requerer a contraprova, o que caracteriza nítidas atitudes de não sujeição do juiz e da contraparte, perfeitamente admissível.

Em resumo, portanto, defende-se que se trata de direito, e não de poder de a parte produzir prova, mas no Brasil a questão não se encontra pacificada e existe precedente jurisprudencial em sentido contrário (STF, 20 I I, online) $)^{3}$.

E o que vem a ser entendido como direito de produzir prova ou direito de provar?

Cambi (20 I 4) entende que se trata do conjunto de oportunidades concedido às partes pela norma, seja constitucional ou infraconstitucional, para que elas possam comprovar a veracidade daquilo que afirmaram em relação aos fatos relevantes para o julgamento da demanda.

Rangel (2006) entende que se trata do direito de as partes conflitantes utilizarem, por via da ação ou da defesa, a prova em seu benefício e como base de seus interesses e pretensões que apresentarem ao tribunal.

Para Echandía (1974), o direito subjetivo de provar, porque depende de um ato de vontade das partes, pode ser abordado sob dois enfoques: i) enquanto complemento dos direitos materiais, porque se trata de direito subjetivo processual em sua essência; e ii) como oportunidade de provar.

De cunho subjetivo, limitado ${ }^{4}$ e eminentemente processual, indica o direito implicitamente assegurado pela Constituição e pelo Código de Processo Civil às partes litigantes ${ }^{5}$, por meio da ação ou da defesa, de empregarem a prova em seu benefício, ou seja, o direito de produzir prova encontra-se consagrado expressamente nas leis adjetivas ou processuais, conforme a lição de Santos (1970), não havendo previsão constitucional explícita no Brasil nem em Portugal.

Entretanto, é possível extrair dos textos constitucionais os fundamentos que sustentam a teoria no sentido de que o direito à prova encontra-se implicitamente consagrado nas Constituições Federais desses países.

Cambi (20।4) não afasta o caráter constitucional do direito de produzir prova e sustenta que se encontra fundado nas garantias constitucionais da ampla defesa, do contraditório e do devido processo legal.

Echandía (1974) sustenta que o direito de provar caracteriza-se como um com-

3 O ministro relator nesse caso destacou que a parte tem o poder de produzir provas.

4 Não se trata de direito absoluto encontrando dentre os seus limites a admissibilidade, a relevância, a pertinência, a necessidade, a utilidade, a razoabilidade, a proporcionalidade e a efetividade.

5 Não se nega o direito de os terceiros intervenientes aceitos na relação jurídica processual produzirem prova, entretanto, deixa-se de incluir a menção em nossa noção. 
plemento do direito de ação do contraditório e da ampla defesa, previsto na Constituição Federal.

Para Rubin (20।3), no Brasil os fundamentos constitucionais do direito prioritário à prova são: acesso adequado ao Judiciário (art. 5, XXXV); devido processo legal (art. 5, LIV); contraditório e ampla defesa (art. 5, LV); provas lícitas (art. 5, LVI).

Ramos (2013) acrescenta que o direito à prova pode ser localizado em dois incisos do art. $5^{\circ}$ da Constituição Federal brasileira: inciso LVI, que trata da proibição das provas ilícitas; e inciso LV, que assegura o contraditório e a ampla defesa aos litigantes.

Didier Júnior (20 I 5) vai além e afirma que o direito à prova é direito fundamental e possui conteúdo complexo, porque se compõe de situações jurídicas específicas: direito à adequada oportunidade de requerer provas; direito de produzir provas; direito de participar da produção da prova; direito de manifestar-se sobre a prova produzida; direito ao exame da prova produzida pelo órgão julgador.

Bedaque ( 1999 ) sustenta que o direito à prova é uma garantia constitucional porque só se pode falar em contraditório efetivo se incluir o poder conferido à parte de empregar todos os meios de prova possíveis e adequados à reconstrução dos fatos descritos no processo, isto é, o direito à prova é componente inafastável do princípio do contraditório, razão pela qual é necessário examiná-lo à luz da garantia constitucional ao instrumento adequado à solução das controvérsias.

Primeiro, o direito de provar encontra-se implicitamente descrito em Tratados e Convenções Internacionais. A Convenção Americana de Direitos Humanos (Pacto de San José da Costa Rica), de 1969, recepcionada pelo Brasil por meio do Decreto $\mathrm{n}^{\circ}$ 678 , de 6 de novembro de 1992, estabeleceu claramente no art. $8^{\circ}$ as garantias judiciais de todos os cidadãos, que, a nosso ver, se estendem aos litigantes em processo civil e fundamentam o direito de provar6. O Pacto Internacional dos Direitos Civis e Políticos, incorporado pelo Decreto n 592, de 1992, no seu art. 14, n³, alínea "e"

6 I. Toda pessoa terá o direito de ser ouvida, com as devidas garantias e dentro de um prazo razoável, por um juiz ou Tribunal competente, independente e imparcial, estabelecido anteriormente por lei, na apuração de qualquer acusação penal formulada contra ela, ou na determinação de seus direitos e obrigações de caráter civil, trabalhista, fiscal ou de qualquer outra natureza. 2. Toda pessoa acusada de um delito tem direito a que se presuma sua inocência, enquanto não for legalmente comprovada sua culpa. Durante o processo, toda pessoa tem direito, em plena igualdade, às seguintes garantias mínimas: (...) c) concessão ao acusado do tempo e dos meios necessários à preparação de sua defesa; d) direito do acusado de defender-se pessoalmente ou de ser assistido por um defensor de sua escolha e de comunicar-se, livremente e em particular, com seu defensor; e) direito irrenunciável de ser assistido por um defensor proporcionado pelo Estado, remunerado ou não, segundo a legislação interna, se o acusado não se defender ele próprio, nem nomear defensor dentro do prazo estabelecido pela lei; f) direito da defesa de inquirir as testemunhas presentes no Tribunal e de obter o comparecimento, como testemunhas ou peritos, de outras pessoas que possam lançar luz sobre os fatos; g) direito de não ser obrigada a depor contra si mesma, nem a confessar-se culpada; e h) direito de recorrer da sentença a juiz ou tribunal superior. 
consagrou o direito à prova7. Nesse passo, essas normas são recepcionadas no Brasil com status de normas constitucionais, a teor da previsão descrita no art. $5^{\circ}, \S 2^{\circ}$, da Constituição Federal, de 1988, de modo que fundamentam o direito de provar. Ademais, para Cambi (200 I), a Constituição Federal, de 1988, não adotou o princípio da tipicidade dos direitos fundamentais, mas sim a fórmula que reconhece a não completude e a provisoriedade do conhecimento científico, viabilizando a visualização de outros direitos que não foram expressamente previstos, como o direito à prova.

Na Europa, existe a Convenção Europeia de Direitos do Homem e das Liberdades Fundamentais, aprovada em Roma, em 1950, recepcionada por Portugal ${ }^{8}$, que previu expressamente no art. $6^{\circ}$ o direito a um processo equitativo que ainda estende o alcance aos litigantes em processo civil ${ }^{9}$.

Em segundo lugar, o recente fenômeno da constitucionalização do direito no Brasil também fundamenta a base constitucional do direito de provar. Segundo Fux (20 | 3), cuida-se da inserção da Constituição como centro de gravidade de toda a ordem jurídica, estabelecendo premissas metodológicas inafastáveis na aplicação da legislação infraconstitucional, o que levou parte da doutrina a admitir a existência de um "direito processual constitucional" que, apesar de não ser um ramo autônomo do direito processual, caracteriza-se como ponto de vista metodológico e sistemático pelo qual se pode analisar o processo em suas conexões com a Constituição (CAMBI, 200 I , p. I 02). $\mathrm{Na}$ atividade hermenêutica, nesse sentido, não se pode ignorar a supremacia da Constituição, notadamente quando se depara com a inserção de regras processuais no bojo da

7 3. Toda pessoa acusada de um delito terá direito, em plena igualmente, a, pelo menos, as seguintes garantias: [...] e) De interrogar ou fazer interrogar as testemunhas de acusação e de obter o comparecimento e o interrogatório das testemunhas de defesa nas mesmas condições de que dispõem as de acusação;

8 Assinatura: 22 de setembro de 1976; Aprovada para ratificação pela Lei nº 65, de 1978 , de 13 de outubro, publicada no Diário da República, I Série, n²36, de 1978 (retificada por Declaração da Assembleia da República publicada no Diário da República, I Série, n 286, de 1978, de 14 de dezembro); Depósito do instrumento de ratificação junto do Secretário-Geral do Conselho da Europa: 9 de novembro de 1978; Aviso de depósito do instrumento de ratificação: Aviso do Ministério dos Negócios Estrangeiros publicado no Diário da República, I Série, $n^{\circ}$ I, de 1979, de 2 de janeiro; Entrada em vigor na ordem jurídica portuguesa: 9 de novembro de 1978.

9 3. O acusado tem, como mínimo, os seguintes direitos: a) Ser informado no mais curto prazo, em língua que entenda e de forma minuciosa, da natureza e da causa da acusação contra ele formulada; b) Dispor do tempo e dos meios necessários para a preparação da sua defesa; c) Defender-se a si próprio ou ter a assistência de um defensor da sua escolha e, se não tiver meios para remunerar um defensor, poder ser assistido gratuitamente por um defensor oficioso, quando os interesses da justiça o exigirem; d) Interrogar ou fazer interrogar as testemunhas de acusação e obter a convocação e o interrogatório das testemunhas de defesa nas mesmas condições que as testemunhas de acusação. 
Carta Maior, e constata-se a existência de princípios no texto constitucional que norteiam o intérprete da norma infraconstitucional. Em assim sendo, existem dois prismas do direito processual constitucional: por um lado, indica a tutela constitucional dos princípios fundamentais da organização judiciária e do processo, ou seja, corresponde às normas constitucionais sobre os órgãos da jurisdição, sua competência e suas garantias; por outro, a jurisdição constitucional que compreende o controle judiciário da constitucionalidade das leis e a jurisdição constitucional das liberdades com o emprego dos remédios constitucionais processuais (CINTRA; GRINOVER; DINAMARCO, 200I , p. 79).

Por último, o direito de provar decorre principalmente dos seguintes princípios consagrados em normas constitucionais: i) devido processo legal; ii) inafastabilidade da jurisdição; iii) contraditório e ampla defesa; iv) isonomia entre as partes.

\section{O DEVIDO PROCESSO LEGAL E O DIREITO DE PRODUZIR PROVA}

princípio do devido processo legal encontra-se previsto nas Constituições do Brasil ${ }^{10}$ e de Portugal' ", na Declaração Universal dos Direitos do Homem ${ }^{12}$, na Convenção Europeia de Direitos Humanos ${ }^{13}$ e implicitamente na Carta dos Direitos Fundamentais da União Europeia'14.

10 Art. $5^{\circ}$ LIV - ninguém será privado da liberdade ou de seus bens sem o devido processo legal.

1 Art. $20^{\circ}$ 4. Todos têm direito a que uma causa em que intervenham seja objecto de decisão em prazo razoável e mediante processo equitativo.

12 Artigo VIII. Toda pessoa tem direito a receber dos tributos nacionais competentes remédio efetivo para os atos que violem os direitos fundamentais que the sejam reconhecidos pela constituição ou pela lei. Artigo X. Toda pessoa tem direito, em plena igualdade, a uma audiência justa e pública por parte de um tribunal independente e imparcial, para decidir de seus direitos e deveres ou do fundamento de qualquer acusação criminal contra ele.

13 Artigo $6^{\circ}$ Direito a um processo equitativo. 1. Qualquer pessoa tem direito a que a sua causa seja examinada, equitativa e publicamente, num prazo razoável por um tribunal independente e imparcial, estabelecido pela lei, o qual decidirá, quer sobre a determinação dos seus direitos e obrigações de caráter civil, quer sobre o fundamento de qualquer acusação em matéria penal dirigida contra ela. $\bigcirc$ julgamento deve ser público, mas o acesso à sala de audiências pode ser proibido à imprensa ou ao público durante a totalidade ou parte do processo, quando a bem da moralidade, da ordem pública ou da segurança nacional numa sociedade democrática, quando os interesses de menores ou a proteção da vida privada das partes no processo o exigirem, ou, na medida julgada estritamente necessária pelo tribunal, quando, em circunstâncias especiais, a publicidade pudesse ser prejudicial para os interesses da justiça.

14 Artigo $47^{\circ}$ Direito à ação e a um tribunal imparcial. Toda a pessoa cujos direitos e liberdades garantidos pelo direito da União tenham sido violados tem direito a uma ação perante um tribunal. Toda a pessoa tem direito a que a sua causa seja julgada de forma equitativa, publicamente e num prazo razoável, por um tribunal independente e imparcial, previamente estabelecido por lei. Toda a pessoa tem a possibilidade de se fazer aconselhar, defender e representar em juízo. 
Significa, em sentido genérico ${ }^{15}$, conforme lição de Nery Júnior (2002), a cláusula que oferece proteção dos direitos fundamentais do cidadão, notadamente, a vida, a liberdade e a propriedade, ou seja, tem-se o direito de tutela àqueles bens da vida em seu sentido mais amplo e genérico e caracteriza-se como o gênero do qual os demais princípios e regras constitucionais são espécies, motivo pelo qual Bulos (2009) afirma que pode ser chamado de sobreprincípio, uma vez que é o fundamento sobre o qual todos os outros direitos fundamentais repousam e, dentre os demais princípios e regras constitucionais, Calmon (2008) cita a publicidade dos atos processuais, a impossibilidade de emprego de prova obtida por meio ilícito, o juiz natural, o contraditório e a ampla defesa.

Em outras palavras, na lição de Canotilho (2003), indica a obrigatoriedade de observar-se um tipo de processo previsto previamente na lei antes de alguém ser privado da vida, da liberdade ou da propriedade, isto é, caracteriza-se como ferramenta imprescindível à manutenção de direitos e garantias fundamentais e consubstancia uma cláusula protetiva das liberdades públicas contra o arbítrio das autoridades dos Poderes Legislativo, Executivo ou Judiciário (BULOS, 2009, p. 288).

Nesse aspecto, o devido princípio legal possui um âmbito de proteção alargado porque vincula não apenas aqueles que fazem parte da relação jurídica processual, ou que atuam diretamente no processo, mas também de todo o aparato jurisdicional, incluindo, assim, todos aqueles que exercem direta ou indiretamente funções qualificadas constitucionalmente como essenciais à justiça (MENDES; BRANCO, 20।5, p. 547).

Em que pese às tentativas de a doutrina delimitar precisamente o seu conceito, Doria (1986) assevera que o due process não pode ser aprisionado em fórmulas porque não é instrumento mecânico nem padrão, antes se caracteriza como processo delicado de adaptação que inevitavelmente envolve o exercício de julgamento por parte de quem se encontra investido da jurisdição.

Com base na lição de Bulos (2009), podem-se elencar dois aspectos do referido princípio: i) em sentido material (substantive due process); e ii) em sentido processual (procedural due process). Essa noção já foi empregada pelo Supremo Tribunal Federal brasileiro (STF, 1996, online).

O primeiro indica a atuação da cláusula no que diz respeito ao direito material, concebido como uma garantia que impõe limites legítimos ao poder estatal, ensejando até mesmo a censura à própria legislação e declaração de ilegitimidade de leis que violem os alicerces do regime democrático (LUCON, 2008, pp. 274-275), o que não interessa a esta investigação.

15 Alinhando ao pensamento norte americano, não há interesse de se estabelecer uma definição precisa do devido processo legal porque atualmente o mais importante é investigar a influência que esse princípio exerce sobre a vida das pessoas e nos seus direitos. 
O segundo estabelece o alcance restrito da expressão devido processo e indica suas repercussões e incidências no campo do direito processual por influência principalmente do direito norte-americano.

O devido processo legal em sentido processual encerra o atendimento de regras pré-determinadas e conhecidas pela legislação processual, objetiva a salvaguarda do próprio processo considerado objetivamente como fator legitimador do exercício da jurisdição e viabiliza a proteção da vida, liberdade e propriedade.

Ávila (20l0) sustenta, nesse sentido, que o princípio do devido processo legal em sentido processual existe para a realização de um estado ideal de protetividade de direitos, mas não indica quais são os comportamentos que podem contribuir para o alcance desse ideal, de modo que se pode falar em três funções dessa cláusula: i) função integrativa, pois cria os elementos necessários à promoção do ideal de protetividade; ii) função interpretativa, porque interpreta as regras que preveem os elementos necessários à promoção desse ideal; iii) função bloqueadora consistente no bloqueio da eficácia de regras que tenham elementos incompatíveis com a promoção do ideal de protetividade.

Por sua vez, Nery Júnior (2002) sustenta que a cláusula procedural due process deve assegurar aos litigantes: i) um juiz imparcial; ii) a oportunidade de deduzir defesa oral perante o juiz; iii) a oportunidade de apresentar provas ao juiz; iv) a chance de reperguntar às testemunhas e de contrariar provas que foram empregadas contra o litigante; v) o direito de ter um defensor no processo perante o juiz ou tribunal; vi) uma decisão fundamentada, com base nas provas produzidas nos autos; vii) o direito a processo com a necessidade de haver provas; viii) o direito de publicar-se e estabelecer-se a conferência preliminar sobre as provas que serão produzidas; ix) o direito a uma audiência pública; x) o direito à transcrição dos atos processuais; xi) o ônus da prova.

Pariz (2009), ao analisar o alcance do significado restrito da expressão dessa cláusula no direito processual americano, explica que deve assegurar ao litigante: i) comunicação adequada sobre a recomendação ou base da ação governamental; ii) juiz imparcial; iii) oportunidade de produção de defesa oral perante o magistrado; iv) faculdade de apresentar provas ao juiz; v) oportunidade de reperguntar testemunhas e contraditar provas empregadas contra o litigante; vi) direito a um defensor no processo perante o magistrado ou tribunal.

De um lado, significa que o princípio do devido processo legal em sua concepção processual indica o direito a um processo com a necessidade de haver provas, bem como a existência do ônus da prova com regras de distribuição claras, porque o princípio se destina, em última análise, a assegurar um julgamento justo para as partes, o que somente pode ser alcançado pelo atendimento das prerrogativas dos litigantes descritas acima (PARIZ, 2009, pp. 183-184), ou seja, deve haver um processo, ele deve ser justo e compatível com os direitos fundamentais (ÁVILA, 20 I0, p. 4I I).

Entretanto, Cambi (200I) sustenta que o direito ao processo justo, por se tratar de conceito indeterminado e cláusula geral, não pode ser definido abstrata- 
mente ao tempo em que seu incumprimento não enseja consequências jurídicas predeterminadas, não obstante ser possível afirmar que o direito ao devido processo justo abrange, também, o direito à tutela jurisdicional adequada e efetiva, que compreende a dinâmica garantia dos meios processuais suficientes e resultado qualitativo, e a isso Cardoso (20/2) acrescenta, ainda, o acesso ao juiz natural, à representação técnica, à paridade de armas, ao contraditório, à ampla defesa, à prova, à publicidade, à motivação da sentença, à assistência jurídica integral e à duração razoável do processo.

De outra banda, Bulos (2009) acrescenta que o devido processo legal na ótica formal destina-se também a assegurar o acesso à justiça, aqui entendido no sentido de expressão máxima de reivindicação do cidadão pelos seus direitos, solucionando seus litígios.

Desse modo, processo justo e acesso à justiça podem ser considerados como faces de uma mesma moeda, ou seja, o acesso à ordem jurídica justa ou à efetiva tutela jurisdicional.

Em assim sendo, ao assegurar o respeito ao devido processo legal, o legislador constituinte estabeleceu implicitamente o direito de provar das partes que se torna extremamente visível pela cláusula procedural due process.

\section{DIREITO DE AÇÃO, CONTRADITÓRIO E PRODUÇÃO DE PROVA}

O direito de ação, previsto em normas de direito internacional|' ${ }^{16}$, encontra-se assegurado tanto na Constituição do Brasil| como na de Portugal|'.

O princípio do direito de ação ou da inafastabilidade da jurisdição, descrito no art. $5^{\circ}, X X X V$, da Constituição Federal, de 1988, estabelece a vedação à autotutela e ao exercício arbitrário das próprias razões e enuncia o processo como instrumento de realização da justiça material.

Dessa forma, assegura a todos a possibilidade de acesso à jurisdição para pleitear a tutela jurisdicional preventiva ou reparatória à lesão ou ameaça de lesão a um direito, seja individual, coletivo, difuso ou individual homogêneo, razão pela qual, para Bulos (2009), caracteriza-se como direito público subjetivo, genérico, abstrato e incondicionado dado a todos, independentemente de raça, credo, condição econômica, posição política ou social.

16 Declaração Universal dos Direitos do Homem, arts. $8^{\circ}, 9^{\circ}$ e $10^{\circ}$, e Convenção Europeia dos Direitos do Homem, arts. $6^{\circ}$ e $13^{\circ}$.

17 Estabelece $\mathrm{o}$ art. $5^{\circ}$, inciso $X X X \mathrm{~V}$, da Constituição Federal brasileira: a lei não excluirá da apreciação do Poder Judiciário lesão ou ameaça a direito;

${ }^{18}$ Art. $20^{\circ}$ (Acesso ao direito e tutela jurisdicional efectiva). I. A todos é assegurado o acesso ao direito e aos tribunais para defesa dos seus direitos e interesses legalmente protegidos, não podendo a justiça ser denegada por insuficiência de meios econômicos. 
Em consequência, nula, e não executável, será toda disposição legal que exclua do pronunciamento judicial certas e determinadas situações jurídicas (CRETELLA JúNIOR, 1997, p. 435).

Na lição de Canotilho e Moreira (2007), o direito de acesso ao direito e à tutela jurisdicional efetiva consiste em direito fundamental constituindo uma garantia indispensável para a proteção de direitos fundamentais, logo, inerente à ideia de Estado de direito que encerra uma incontornável dimensão prestacional a cargo do Estado que deve colocar à disposição dos indivíduos uma organização judiciária e um conjunto de processos garantidores da tutela jurisdicional efetiva. Segundo os autores, o preceito encerra vários direitos conexos e distintos, dentre os quais o direito de acesso ao direito; o direito de acesso aos tribunais; o direito à informação e consultas jurídicas; o direito ao patrocínio judiciário, uma vez que todos são componentes de um direito geral à proteção jurídica.

Nesse aspecto, o direito de acesso à jurisdição engloba, também, o direito à produção de prova pelas partes no processo, uma vez que a concretização do acesso a esses direitos conexos somente é concebido a partir do respeito às normas processuais, dentre as quais aquelas que estabelecem as regras para a produção da prova perante o juiz.

Ademais, o direito à proteção jurídica abrange todos os direitos e interesses legalmente protegidos, e o direito à produção da prova, sem dúvida, que se encontra albergado pela norma jurídica.

E mais, o direito de ação conduz à possibilidade de a parte agir em juízo, o que significa que pode realizar no processo todas as atividades necessárias à obtenção da tutela jurisdicional requerida, o que inclui a produção de provas. Implica que o direito de ação não se limita à instauração do processo, mas fundamenta a própria prerrogativa de agir da parte no curso do procedimento, e sua atuação inclui a possibilidade de utilização dos meios probatórios admissíveis e relevantes para a demonstração dos fatos deduzidos como fundamento da pretensão.

Por fim, o direito de ação não significa direito ao processo, mas direito ao processo justo, no qual se encontra o direito à prova, conforme já consignado anteriormente quando da abordagem do princípio do devido processo legal.

Em Portugal, Jorge (2008) informa que o Tribunal Constitucional já se manifestou no sentido de que o direito de ação enseja para a parte o direito de oferecer suas provas e controlar as provas do adversário.

Portanto, o direito de produzir prova também se encontra implicitamente protegido pela norma constitucional que trata do acesso à jurisdição.

A essa altura, resta saber se o direito à produção de provas estaria legitimado pelo princípio do contraditório 19, consagrado em tratados e convenções interna-

19 Não se fez distinção entre o contraditório e a ampla defesa na presente investigação porque se entende que merecem tratamento comum na medida em que se trata de expressões diferentes para identificar o mesmo fenômeno e que se encontram no mesmo dispositivo 
cionais20, também nas Constituições do Brasil2I e de Portugal22, no Código de Processo Civil, de 20 I 523, e no Código de Processo Civil Português (CPCpt)24.

De acordo com Cabral (2005), o princípio do contraditório deriva do princípio da dignidade da pessoa humana, porque no processo o homem não pode ser considerado meramente um objeto, mas assume um papel ativo de sujeito processual.

Almeida (1973, p. 82) entende que o contraditório "é a ciência bilateral dos atos e termos processuais e a possibilidade de contrariá-los".

Na lição de Bulos (2009), dois são os elementos da noção de contraditório: i) necessidade de bilateralidade, caracterizada pela informação necessária às partes; e ii) possibilidade de reação, atrelada a uma reação possível. Segundo o autor, o contraditório possui como conteúdo assegurar aos litigantes o direito de ação e o direito de defesa, assegurando-se a igualdade das partes, de modo que todos aqueles que possuírem alguma pretensão a ser deduzida em juízo podem invocar o contraditório. No mesmo sentido, Grinover (1990) entende que se desdobra o contraditório em dois momentos: a informação necessária e a reação possível.

Todavia, segundo Oliveira (2013), atualmente o contraditório pode ser entendido

constitucional.

20 Declaração Universal dos Direitos do Homem, art. I I. Convenção Americana de Direitos Humanos, art. $8^{\circ}, n^{\circ} 2$.

${ }^{21}$ Art. $5^{\circ}, \mathrm{LV}$ - aos litigantes, em processo judicial ou administrativo, e aos acusados em geral são assegurados o contraditório e ampla defesa, com os meios e recursos a ela inerentes; 22 Art. $32^{\circ}, 5$. O processo criminal tem estrutura acusatória, estando a audiência de julgamento e os actos instrutórios que a lei determinar subordinados ao princípio do contraditório.

${ }^{23}$ Art. $7^{\circ}$ É assegurada às partes paridade de tratamento em relação ao exercício de direitos e faculdades processuais, aos meios de defesa, aos ônus, aos deveres e à aplicação de sanções processuais, competindo ao juiz zelar pelo efetivo contraditório. Art. $9^{\circ}$. Não se proferirá decisão contra uma das partes sem que esta seja previamente ouvida. Art. I0. O juiz não pode decidir, em grau algum de jurisdição, com base em fundamento a respeito do qual não se tenha dado às partes oportunidade de se manifestar, ainda que se trate de matéria sobre a qual deva decidir de ofício.

${ }^{24}$ Art. $372^{\circ}, 1$ - Quando o requerido não tiver sido ouvido antes do decretamento da providência, é-lhe lícito, em alternativa, na sequência da notificação prevista no n. ${ }^{\circ} 6$ do artigo 366. : a) Recorrer, nos termos gerais, do despacho que a decretou, quando entenda que, face aos elementos apurados, ela não devia ter sido deferida; b) Deduzir oposição, quando pretenda alegar factos ou produzir meios de prova não tidos em conta pelo tribunal e que possam afastar os fundamentos da providência ou determinem a sua redução, aplicando -se, com as adaptações necessárias, o disposto nos artigos $367^{\circ}$ e $368^{\circ}$. Art. 597\%. Nas ações de valor não superior a metade da alçada da Relação, findos os articulados, sem prejuízo do disposto no $n^{\circ} 2$ do artigo $590{ }^{\circ}$, o juiz, consoante a necessidade e a adequação do ato ao fim do processo: a) Assegura o exercício do contraditório quanto a exceções não debatidas nos articulados; 
de maneira mais ampla, como a outorga de prerrogativas para que as partes participem no desenvolvimento e no resultado do processo de maneira paritária, influenciando de forma ativa e efetiva a formação dos pronunciamentos jurisdicionais, afinal, o processo deve ser estruturado em torno da possibilidade de efetiva participação das partes e na ideia de simétrica paridade entre estas, razão pela qual se aplica o entendimento de Cambi (200 I), o de que o contraditório é sinônimo de participação processual. É nesse sentido que Cabral (2005) afırma que o contraditório também pode ser entendido como o direito de as partes influenciarem o exercício do poder do Estado.

Nesse contexto, já foram tecidas algumas considerações sobre o direito de ação e quanto ao direito de defesa, consubstanciado pelo princípio do contraditório, Grinover (1990) aduz que o demandado deve ter assegurado o mesmo tratamento dado ao demandante, sob pena de violação do princípio da isonomia das partes, as quais merecem proteção equivalente, pois assegurada a paridade de armas entre os litigantes e notadamente porque ação e defesa são dois direitos iguais e contrapostos.

Então, o direito de defesa indica a possibilidade de o demandado valer-se de todos os instrumentos úteis e necessários para influenciar no convencimento do juiz, o que inclui a sua iniciativa probatória. Esse direito de defesa, por ser dinâmico, estende-se durante todo o desenvolvimento da relação jurídica processual até decisão do juiz conhecendo, ou não, da pretensão do autor e acolhendo ou a rejeitando.

Entretanto, Oliveira (2013) assevera que não apenas o direito de defesa encontra-se albergado pelo contraditório, mas também outras manifestações das partes no curso do processo, ou seja, deve-se dar oportunidade igual a que cada litigante possa ter acesso às provas produzidas no feito pelo adversário (direito à informação) e possa, assim, preparar sua reação em tempo hábil, de maneira efetiva (reação), conforme estabelecido, por exemplo, pelo art. 398 do Código de Processo Civil, de 197325 (art. 437, § 1 ${ }^{\circ}$, do Código de Processo Civil, de20 I 526) e arts. 4I 5, I27, e $427^{\circ} 28$ do Código de Processo Civil Português, afinal o contraditório permeia todos os atos do procedimento.

De tal sorte, o contraditório vai além do simples direito de defesa e assegura a participação paritária e efetiva das partes no curso do processo, por meio de regras

25 Art. 398. Sempre que uma das partes requerer a juntada de documento aos autos, o juiz ouvirá, a seu respeito, a outra, no prazo de 5 (cinco) dias.

26 § I o Sempre que uma das partes requerer a juntada de documento aos autos, o juiz ouvirá, a seu respeito, a outra parte, que disporá do prazo de 15 (quinze) dias para adotar qualquer das posturas indicadas no art. 436.

27 | - Salvo disposição em contrário, não são admitidas nem produzidas provas sem audiência contraditória da parte a quem hajam de ser opostas.

${ }^{28}$ Quando o documento seja oferecido com o último articulado ou depois dele, a sua apresentação é notificada à parte contrária, salvo se esta estiver presente ou o documento for oferecido com alegações que admitam resposta. 
pontuais na legislação processual civil, como, por exemplo, as descritas no Código de Processo Civil, de 1973, nos arts. $407^{29}$ (art. 357, §4 ${ }^{\circ}$, do Código de Processo Civil, de 201530); 433, parágrafo único ${ }^{31}$ (art. 477, $\S 1^{\circ}$, do Código de Processo Civil, de 201532); 442, parágrafo único 33 (art. 483, parágrafo único, do Código de Processo Civil , de $2015^{34}$ ); e arts. $552^{\circ}, 2^{35}$ e $485^{\circ}$, I e 2, do Código de Processo Civil Português ${ }^{36}$.

E na busca pelo processo justo, assim não poderia ser diferente, em virtude do princípio da dialeticidade do processo, porque para todo movimento realizado por uma parte deve ser assegurada a oportunidade para que o adversário possa realizar outro movimento com o fim de contrastar e de minimizar os efeitos do ato que o precede, ou seja, na lição de Cambi (200l), conferem-se oportunidades razoáveis às partes para que realizem o ato juridicamente admissível que consideram o mais apropriado para neutralizar o movimento contrário.

Assim, segundo Grinover (1975, p. 7), "o contraditório consiste na ciência, por ambas as partes, do que se faz ou se pretende fazer no processo, e na possibilidade de contrariar", impondo no processo a oportunidade para a parte manifestar-se em momento precedente ao da decisão judicial.

29 Art. 407. Incumbe às partes, no prazo que o juiz fixará ao designar a data da audiência, depositar em cartório o rol de testemunhas, precisando-lhes o nome, profissão, residência e o local de trabalho; omitindo-se o juiz, o rol será apresentado até 10 (dez) dias antes da audiência.

30 § 40 Caso tenha sido determinada a produção de prova testemunhal, o juiz fixará prazo comum não superior a I 5 (quinze) dias para que as partes apresentem rol de testemunhas.

31 Art. 433. O perito apresentará o laudo em cartório, no prazo fixado pelo juiz, pelo menos 20 (vinte) dias antes da audiência de instrução e julgamento. Parágrafo único. Os assistentes técnicos oferecerão seus pareceres no prazo comum de 10 (dez) dias, depois de intimadas as partes da apresentação do laudo.

$32 \S$ I o As partes serão intimadas para, querendo, manifestar-se sobre o laudo do perito do juízo no prazo comum de 15 (quinze) dias, podendo o assistente técnico de cada uma das partes, em igual prazo, apresentar seu respectivo parecer.

33 Parágrafo único. As partes têm sempre direito a assistir à inspeção, prestando esclarecimentos e fazendo observações que reputem de interesse para a causa.

34 Parágrafo único. As partes têm sempre direito a assistir à inspeção, prestando esclarecimentos e fazendo observações que considerem de interesse para a causa.

352 - No final da petição, o autor deve apresentar o rol de testemunhas e requerer outros meios de prova; caso o réu conteste, o autor é admitido a alterar o requerimento probatório inicialmente apresentado, podendo fazê-lo na réplica, caso haja lugar a esta, ou no prazo de 10 dias a contar da notificação da contestação.

36 I - A apresentação do relatório pericial é notificada às partes. 2 - Se as partes entenderem que há qualquer deficiência, obscuridade ou contradição no relatório pericial, ou que as conclusões não se mostram devidamente fundamentadas, podem formular as suas reclamações. 
Portanto, a oportunidade deve estar alicerçada na paridade de armas ou par condicio, que significa o princípio de equilíbrio de situações, não iguais, mas recíprocas (GRINOVER, 1990, p. 7), de modo a assegurar o equilíbrio entre as partes de forma que ambas tenham possibilidades equivalentes de participar da marcha e do resultado do processo por meio dos mesmos instrumentos processuais, fazendo valer seus direitos em igualdade de condições, conforme estabelece o art. 125, inciso I, do Código de Processo Civil, de 197337 (art. 139, inciso I, do Código de Processo Civil, de 2015, com redação idêntica), e art. $4^{\circ}$ do Código de Processo Civil Português38.

Conforme Picardi (1998), assegura-se às partes a paridade de armas, por meio de uma justaposição de teses que tornam o princípio do contraditório um verdadeiro instrumento de luta das partes. Dinamarco ( | 98|) sustenta, nesse contexto, que não basta o contraditório ser efetivo, mas sim equilibrado, e o equilíbrio consiste na ideia de igualdade das partes consubstanciada na igualdade de oportunidades no processo.

Logo, de um lado, pode-se falar em três conteúdos de eficácia mínima do contraditório: i) igualdade substancial com a remoção de todos os obstáculos internos e, se possível, externos ao processo; ii) garantia da defesa técnica; iii) adequação qualitativa das possibilidades de se fazer ouvir pelo juiz (CAMBI, 200 I, pp. 134- I35).

Especificamente sobre a defesa técnica, somente poderá ser exercida minimamente se, de um lado, oportunizar o conhecimento da parte sobre as alegações da parte contrária e, por outro, viabilizar a produção de todos os meios de prova relevantes para demonstrar a alegação da parte, isto é, o contraditório não será exercido sequer minimamente se não for assegurada a iniciativa probatória dos litigantes.

De outra forma, porém, o ideal perseguido é o de processo justo, de modo que o contraditório deve alcançar a sua máxima amplitude para que possa viabilizar esse objetivo. Nesse passo, Grinover (1990) aduz que a participação da parte na instrução não se limita à iniciativa probatória, mas estende-se sobretudo quanto sirva para preparar o espírito do juiz, ou seja, alcança todos os atos capazes de influir na formação do convencimento do julgador, pela prova e fora da prova, de modo que instruir, na lição de Dinamarco ( 198 I), não se limita a provar, mas sim preparar o provimento final.

Ainda a efetividade e a plenitude do contraditório somente poderão ser alcançadas se o princípio for estimulado pelo julgador pela verificação do desempenho adequado das atividades defensivas e emprego de todos os meios necessários para influir sobre seu convencimento, sem que com isso venha a perder a sua imparciali-

${ }^{37}$ Art. 125. O juiz dirigirá o processo conforme as disposições deste Código, competindo-lhe: I - assegurar às partes igualdade de tratamento.

${ }^{38}$ Art. $4^{\circ}$. O tribunal deve assegurar, ao longo de todo o processo, um estatuto de igualdade substancial das partes, designadamente no exercício de faculdades, no uso de meios de defesa e na aplicação de cominações ou de sanções processuais. 
dade (GRINOVER, 1990, pp. I I- I2).

Segundo Barbosa Moreira ( 1984), a maneira de exorcizar o fantasma da parcialidade consiste exatamente em submeter a atividade do juiz à observância do contraditório, proibindo de levar em conta na sua decisão qualquer elemento probatório colhido sem que as partes tivessem a oportunidade efetiva de participar, na medida do possível, seja na sua colheita ou, no mínimo, na manifestação dos resultados obtidos. De tal sorte que essa atuação mais ativa na direção e na instrução do feito por parte do juiz não implica necessariamente instaurar no processo civil o domínio do "autoritarismo" ou do "paternalismo" porque os papéis do juiz e o das partes se completam e não se excluem (BARBOSA MOREIRA, 1985, pp. 147- I48).

Outro argumento que legitima o contraditório como fundamento do direito à prova, de acordo com Ribeiro (2014), encontra-se no fato de que a validade da prova somente existirá se houver respeito ao contraditório, e assim ocorre porque é necessária a presença do juiz e das partes na produção da prova: o primeiro, como condutor do procedimento na presença de quem todas as provas devem ser produzidas, a teor do disposto no art. 336, caput, do Código de Processo Civil, de $1973^{39}$ (art. 449 do Código de Processo Civil, de $2015^{40}$ ) e art. $500^{\circ}$ do Código de Processo Civil Português ${ }^{41}$; e às partes, seja por meio do pedido de produção de provas seja por pedido de contraprova, é assegurado o direito de participarem diretamente da produção da prova.

A participação direta do juiz durante todo o desenvolvimento da atividade processual é fator indispensável ao atendimento do contraditório, pois o exercício da jurisdição implica a tarefa de o juiz participar diretamente de todos os atos do processo, o que o coloca como destinatário do contraditório, na acepção de Mesquita (2003).

Além disso, de acordo com Oliveira (1992), as partes não se sujeitam passivamente à definição jurídica ou fática da causa efetuada pelo julgador, antes dispõem da possibilidade de se pronunciarem e intervirem ativamente no processo porque

39 Art. 336. Salvo disposição especial em contrário, as provas devem ser produzidas em audiência.

40 Art. 449. Salvo disposição especial em contrário, as testemunhas devem ser ouvidas na sede do juízo.

${ }^{41}$ As testemunhas depõem na audiência final, presencialmente ou através de teleconferência, exceto nos casos seguintes: a) Inquirição antecipada, nos termos do artigo 4l9'; b) Inquirição por carta rogatória, ou por carta precatória expedida para consulado português que não disponha de meios técnicos para a inquirição por teleconferência; c) Inquirição na residência ou na sede dos serviços, nos termos do artigo 503; d) Impossibilidade de comparência no tribunal; e) Inquirição reduzida a escrito, nos termos do artigo 517\%; f) Depoimento prestado por escrito, nos termos do artigo $518^{\circ}$; g) Esclarecimentos prestados nos termos do artigo $520^{\circ}$ 
possuem o direito de atuar de maneira crítica e construtiva no curso do processo.

Dessa forma, o princípio do contraditório assume a função de princípio, guia de um verdadeiro debate processual, rendendo a possibilidade de exercício do direito de as partes influenciarem a formação da vontade estatal, e impondo deveres às partes de colaborarem na formação da convicção do magistrado e a este o dever de promover no processo um ambiente propício para o debate (CABRAL, 2005, p. 464).

Pelo visto até o momento, os direitos de ação e de defesa careceriam de conteúdo substancial não fosse o direito à prova, porque impedir a parte de produzir prova significa privá-la dos meios legítimos de acesso à ordem jurídica justa, na lição de Cambi (200 I), a ponto de se encontrar na doutrina a posição de Comoglio ( 1998), no sentido de que o exercício desses direitos - de ação e de defesa - nem mesmo estaria sujeito à preclusão.

Dessa forma, somente se pode falar de maneira efetiva em justiça, inerente à garantia do devido processo legal, quando, no curso do processo, a ação e a defesa possam vir a ser exercidas adequadamente, e o direito de produzir prova, nesse sentido, é um dos pilares para o exercício desses direitos protegidos constitucionalmente, motivo pelo qual fundamentam a ideia defendida no sentido de que o direito de provar encontra-se implicitamente protegido, também, pelos princípios da inafastabilidade da jurisdição e do contraditório.

\section{A ISONOMIA ENTRE AS PARTES E A INICIATIVA PROBATÓRIA}

A Declaração Universal dos Direitos do Homem contemplou o princípio da igualdade nos seus arts. $1^{\circ}$ e $2^{\circ 42}$ no que foi seguida pela Convenção Europeia de Direitos Humanos (art. 140 $)^{43}$ e pela Convenção Americana sobre Direitos Humanos (art. 24) $)^{44}$.

42 Artigo $1^{\circ}$. Todos os seres humanos nascem livres e iguais em dignidade e em direitos. Dotados de razão e de consciência, devem agir uns para com os outros em espírito de fraternidade. Artigo $2^{\circ}$. Todos os seres humanos podem invocar os direitos e as liberdades proclamados na presente Declaração, sem distinção alguma, nomeadamente de raça, de cor, de sexo, de língua, de religião, de opinião política ou outra, de origem nacional ou social, de fortuna, de nascimento ou de qualquer outra situação. Além disso, não será feita nenhuma distinção fundada no estatuto político, jurídico ou internacional do país ou do território da naturalidade da pessoa, seja esse país ou território independente, sob tutela, autônomo ou sujeito a alguma limitação de soberania.

${ }^{4}$ Artigo $14^{\circ}$. O gozo dos direitos e liberdades reconhecidos na presente Convenção deve ser assegurado sem quaisquer distinções, tais como as fundadas no sexo, raça, cor, língua, religião, opiniões políticas ou outras, a origem nacional ou social, a pertença a uma minoria nacional, a riqueza, o nascimento ou qualquer outra situação.

44 Artigo 24. Todas as pessoas são iguais perante a lei. Por conseguinte, têm direito, sem 
No Brasil, o princípio da igualdade encontra-se descrito no caput do art. $5^{\circ}$ da Constituição Federal, de $1988^{45}$.

A Constituição da República Portuguesa, por sua vez, consagra o princípio da igualdade no seu art. $13^{046}$ e, conforme Miranda (1982), indica a necessidade de igualdade jurídica e social, ou seja, a primeira estabelecendo que a lei é igual para todos, o que implica a proibição de privilégios e de discriminações, vedando a diferenciação das pessoas com base em classes jurídicas diversas, com diferentes direitos e deveres, de acordo com o nascimento, a raça, o sexo etc., e significa que a lei deve ser igual para todos; a igualdade social consubstanciada no livre acesso aos benefícios da civilização pela transformação das estruturas econômico-sociais.

Em primeiro lugar, de um lado, o princípio da igualdade dirige-se à criação do direito, conforme a jurisprudência do Tribunal Constitucional Federal alemão citada por Alexy (2007), de modo que vincula o legislador. Segundo o autor, o princípio da igualdade na criação do direito exige que todos sejam tratados igualmente pelo legislador, o que não significa, porém, que tenha de colocar todas as pessoas nas mesmas posições jurídicas porque conduziria não apenas a normas não funcionais e injustas, como também eliminaria os pressupostos para o exercício de competências; nem que tenha de procurar que todos apresentem as mesmas propriedades naturais ou se encontrem nas mesmas situações fáticas, pois a eliminação das diferenças encontraria óbice em limites naturais e limitaria o nível intelectual, cultural ou econômico do homem.

Por outro lado, Canotilho e Moreira (2007) aduzem que o princípio da igualdade é um dos princípios estruturantes do sistema constitucional global, albergando as dimensões liberais, democráticas e sociais inerentes ao conceito de Estado de direito democrático e social, notadamente porque impõe a igualdade na aplicação do direito, assegurada pela universalidade da lei e pela vedação de diferenciação entre cidadãos com base em condições meramente subjetivas.

Em assim sendo, Cintra ( 1982 ) afirma que o princípio da igualdade dirige-se, em primeiro lugar, ao próprio legislador a quem é vedado fazer discriminações desarrazoadas entre as pessoas, mas também se dirige ao juiz e ao administrador, o que indica que todos são iguais perante o magistrado a quem compete dar à lei o enten-

discriminação, a igual proteção da lei.

45 Art. $5^{\circ}$ Todos são iguais perante a lei, sem distinção de qualquer natureza, garantindo-se aos brasileiros e aos estrangeiros residentes no País a inviolabilidade do direito à vida, à liberdade, à igualdade, à segurança e à propriedade, nos termos seguintes:

${ }^{46}$ Artigo $13^{\circ}$ (Princípio da igualdade). I. Todos os cidadãos têm a mesma dignidade social e são iguais perante a lei. 2. Ninguém pode ser privilegiado, beneficiado, prejudicado, privado de qualquer direito ou isento de qualquer dever em razão de ascendência, sexo, raça, língua, território de origem, religião, convicções políticas ou ideológicas, instrução, situação econômica, condição social ou orientação sexual. 
dimento que não gere privilégios de espécie alguma entre as partes.

Significa que a isonomia ignora as desigualdades reais para estabelecer igualdade formal, ou igualdade jurídica, ou igualdade jurídico-formal (SILVA, 200 I , p. 2I 4), motivo pelo qual Cintra ( 1982 ) afirma que essa igualdade decorre da lei, e não da realidade, de modo que se justifica a possibilidade de haver distinções entre os homens, à luz da realidade, sem que haja violação da isonomia, reduzindo a distância entre a ficção e a realidade e viabilizando o alcance do processo justo, afinal o princípio da isonomia não é absoluto, como nenhum direito o é.

Entretanto, no âmbito da relação jurídica processual, atualmente não basta assegurar a igualdade formal entre os litigantes, deve o magistrado perseguir a promoção da igualdade real entre as partes, o que somente poderá ser verificado quando a solução encontrada não resultar da superioridade econômica ou da astúcia de uma delas, e para que se possa falar em igualdade real, efetiva, deve ser assegurado às partes o adequado equilíbrio, independentemente de fatores externos (BEDAQUE, 2013, p. 109).

Às partes não deve ser oferecida somente a oportunidade, mas garantir que essas oportunidades sejam aproveitadas por todas as partes independentemente das desigualdades econômicas ou sociais.

Nesse passo, o tratamento isonômico às partes significa tratar igualmente os iguais e desigualmente os desiguais, na medida de suas desigualdades.

Para Alexy (2007), essa fórmula pode ser interpretada de duas maneiras distintas. Pela primeira interpretação, o princípio limita-se à prática de decisão universalista, ou seja, o legislador deve adotar normas universais condicionadas a partir da consideração da presença de certas propriedades das pessoas que devem receber o tratamento igual ou desigual. Entretanto, segundo o próprio autor, essa interpretação não pode ser aceita, uma vez que não explica como devem ser tratados quais indivíduos e com quais propriedades, o que poderia dar margem a discriminações por parte do legislador sem que caracterizassem violação ao princípio da igualdade. Conforme a segunda interpretação, a exigência deve dirigir-se ao conteúdo da norma, e não à formulação lógica da norma. Nesse contexto, explica o autor que se deve ter em consideração a igualdade ou desigualdade valorativa, isto é, relativa a igualdades (desigualdades) fáticas parciais e à igualdade valorativa relativa a determinados tratos.

Com base em Didier Júnior (2006), tratar igualmente os iguais e desigualmente os desiguais indica que não existe simetria perfeita de direitos e obrigações, valendo a máxima segundo a qual eventuais diferenças de tratamento devem ser justificadas racionalmente, com base em critérios de reciprocidade, de forma a evitar que haja desequilíbrio global em prejuízo de uma das partes.

No processo civil brasileiro, por exemplo, encontram-se prerrogativas à Fazenda Pública e ao Ministério Público, como dilação de prazo e reexame necessário, instituídas com vista ao interesse público em virtude da natureza e organização do Estado. Ainda se encontra norma autorizando a inversão do ônus da prova em benefício 
do consumidor, desde que presentes os requisitos presentes na norma.

Dessa forma, a igualdade extrapola esses parâmetros de diferenciação das pessoas e alcança a relação jurídica processual, seja como consequência direta do due process of Law, seja porque ela teve seu âmbito alargado e hoje se configura como um princípio disciplinador de toda a atividade pública nas suas relações com os cidadãos (CANOTILHO; MOREIRA, 2007, p. 338).

Nesse passo, com relação à jurisdição, Canotilho e Moreira (2007) asseveram que o princípio da igualdade comporta três dimensões: i) igualdade de acesso dos cidadãos à jurisdição (art. 20, I, da Constituição portuguesa); ii) igualdade dos cidadãos perante os tribunais; iii) igualdade da aplicação do direito aos cidadãos por meio dos tribunais.

E é nesse segundo aspecto que o princípio da igualdade incide claramente sobre o direito à produção de provas, pois garante a igualdade de armas no processo e a igualdade na posição de sujeito processual, o que implica proibição de discriminação das partes no processo, nos termos do art. 125, inciso I, do Código de Processo Civil, de 1973 (art. 139, inciso I, do Código de Processo Civil, de 20 I 5, com redação idêntica), de modo que se pode afirmar que esse princípio, ainda que implicitamente, legitima às partes a oportunidade de produzir provas no processo.

Em outras palavras, na forma dialética de colaboração das partes, Cintra (1982) aduz que elas se colocam perante o Estado-Juiz em pé de igualdade, apresentando racionalmente seus argumentos e suas provas para que sejam avaliados pelo seu próprio valor, e não com base em quem os apresentou, presumindo, assim, a sua igualdade.

Implica reconhecer que o magistrado possui um papel fundamental nesse contexto, porque a ele se impõe atuação para minorar as desigualdades reais existentes entre os litigantes, agindo, porém, com a maior cautela possível, a fim de não promover maior desigualdade.

No Brasil, o Supremo Tribunal Federal já se pronunciou no sentido de que o tratamento igualitário das partes é a medula do devido processo legal, de modo que não cabe interpretação para afastá-lo (STF, 2003, online).

\section{CONCLUSÃO}

Ao longo deste estudo, procurou-se analisar a prova civil à luz dos princípios constitucionais que mantêm relação estreita com a matéria, e diante de todo o exposto podem-se extrair algumas conclusões:

I. As partes têm assegurado o direito constitucional - e não poder - de produzir provas pelos seguintes motivos: i) são sujeitos de direitos e deveres processuais; ii) a Constituição não previu norma outorgando poderes às partes; iii) a parte não tem o dever de produzir prova, somente o ônus processual; iv) o poder é irrenunciável por parte de seu detentor, mas os direitos processuais costumam ser renunciáveis; v) as partes não podem sujeitar o juiz no curso do processo.

2. O direito de provar decorre implíita e principalmente dos seguintes princípios consagrados em normas constitucionais: i) devido processo legal; ii) inafastabilidade 
da jurisdição; iii) contraditório e ampla defesa; iv) isonomia entre as partes.

3. A cláusula procedural due process deve assegurar aos litigantes o direito a um processo com a necessidade de haver provas, bem como a existência do ônus da prova com regras de distribuição claras.

4. $\bigcirc$ direito ao devido processo justo abrange o direito à tutela jurisdicional adequada e efetiva, que compreende a dinâmica garantia dos meios processuais suficientes e resultado qualitativo.

5. $\bigcirc$ direito de ação não significa direito ao processo, mas direito ao processo justo, no qual se encontra o direito à prova.

6. $O$ direito de defesa indica a possibilidade do demandado de valer-se de todos os instrumentos úteis e necessários para influenciar no convencimento do juiz, o que inclui a sua iniciativa probatória.

7. Em virtude da forma dialética de colaboração das partes, assegura-se a elas a possibilidade de apresentarem racionalmente seus argumentos e suas provas para que sejam avaliados pelo seu próprio valor, e não com base em quem os apresentou, presumindo, assim, a sua igualdade.

\section{REFERÊNCIAS}

ALEXY, Robert. Teoría de los derechos fundamentales. Traducción y estúdio introductorio de Carlos Bernal Pulido. Madri: Centro de Estudios Politicos y Constitucionales, 2007.

ALMEIDA, Joaquim Canuto Mendes de. Princípios fundamentais do processo penal. São Paulo: Editora Revista dos Tribunais, 1973.

AROCA, Juan Montero. La prueba en el proceso civil. Navarra: Thomson Reuters, 2011 .

ÁVILA, Humberto. O que é "Devido Processo Legal"? In: DIDIER JR, Fredie (Org.). Leituras Complementares de Processo Civil. Salvador: Editora Juspodivm, 2010 , pp. 405-4| 4 .

BARBOSA MOREIRA, José Carlos. A função social do processo civil moderno e o papel do juiz e das partes na direção e na instrução do processo. In: Revista de Processo, n 37, pp. 140-150, janeiro/março de 1985. de 1984.

. O juiz e a prova. In: Revista de Processo, n 35, pp. 189-184, abril/junho

BEDAQUE, José Roberto dos Santos. Garantia da amplitude de produção probatória. In: TUCCl, José Rogério Cruz e (Coord.). Garantias constitucionais do processo civil. São Paulo: Editora Revista dos Tribunais, 1999, p. I5I-189. 
Poderes instrutórios do juiz. São Paulo: Editora Revista dos Tribunais, 2013.

BRASIL. Constituição da República Federativa do Brasil de 1988. Disponível em: <http://www.planalto.gov.br/ccivil_03/constituicao/constituicaocompilado.htm>. Acesso em: 8 set. 2018.

. Lei no 5.869, de II de janeiro de 1973. Institui o Código de Processo Civil. Disponível em: <http://www.planalto.gov.br/ccivil_03/leis/L5869.htm>. Acesso em: 8 set. 2018.

. Lei no 13. I 05, de 16 de março de 20 I 5. Código de Processo Civil. Disponível em: < http://www.planalto.gov.br/ccivil_03/_ato20 I5-20 I8/20 I5/lei/I3 I 05.htm>. Acesso em: 8 set. 2018.

Supremo Tribunal Federal. Ação direta de inconstitucionalidade $n^{\circ} \mid$ I.5 I MC, Relator: Ministro Carlos Velloso; Julgado em 16 out. 1996. Disponível em: $<$ http://redir.stf.jus.br/paginadorpub/paginador.jsp?docTP=AC\&doclD $=347$ | 05>. Acesso em: 8 set. 2018.

. Supremo Tribunal Federal. Habeas Corpus no 83.255, Relator: Ministro Marco Aurélio; Julgado em: 5 nov. 2003. Disponível em: < http://redir.st.jus.br/ paginadorpub/paginador.jsp?docTP $=A C \& d o c \mid D=79303>$. Acesso em: 9 set. 2018 .

. Supremo Tribunal Federal. Habeas Corpus n 84.965, Relator: Ministro Gilmar Mendes, Segunda Turma; Julgado em: 13 dez. 20 I I, Disponível em: <http:// redir.stf.jus.br/paginadorpub/paginador.jsp?docTP $=T P \& d o c|D=| 899767>$. Acesso em: 8 set. 2018.

BULOS, Uadi Lammêgo. Constituição Federal anotada. São Paulo: Editora Saraiva, 2009.

CABRAL, Antônio do Passo. Il principio del contraddittorio come diritto d'influenza e dovere di dibattito. In: Rivista di Diritto Processuale, anno LX, n. 2, aprile/giugno 2005, pp. 449-450.

CALMON, Eliana. Princípios e Garantias Constitucionais do Processo. In: MARTINS, Ives Gandra da Silva; JOBIM, Eduardo (Coord.). O Processo na Constituição. São Paulo: Editora Quartier Latin do Brasil, 2008.

CAMBI, Eduardo. Curso de Direito Probatório. Curitiba: Juruá Editora, 2014.

. Direito constitucional à prova no processo civil. São Paulo: Editora Revista dos Tribunais, $200 \mathrm{I}$.

CANOTILHO, J. J. Gomes. Direito Constitucional e Teoria da Constituição. 
Coimbra: Livraria Almedina, 2003, p. 493.

CANOTILHO, J. J. Gomes; MOREIRA, Vital. Constituição da República Portuguesa Anotada, volume I. Coimbra: Coimbra Editora, 2007.

CARDOSO, Oscar Valente. Direitos fundamentais do processo: devido processo legal e devido processo justo. In: Revista Dialética de Direito Processual, $n^{\circ} \mid 17$, pp. 6I-7I, dezembro 2012.

CARNELUTTI, Francesco. Sistema de direito processual civil, volume I. Traduzido por Hiltomar Martins Oliveira. São Paulo: Classic Book, 2000a.

Sistema de direito processual civil, volume II. Traduzido por Hiltomar Martins Oliveira. São Paulo: Classic Book Editora e Distribuidora de Livros Ltda., 2000b.

CARVALHO, Kildare Gonçalves. Direito constitucional. Belo Horizonte: Editora Del Rey, 2007.

CINTRA, Antônio Carlos de Araújo. $\bigcirc$ princípio da igualdade processual. In: Revista da Procuradoria Geral do Estado de São Paulo, n 19, pp. 39-44, dez. I981/dez. 1982.

CINTRA, Antônio Carlos de Araújo; GRINOVER, Ada Pellegrini; DINAMARCO, Cândido Rangel. Teoria Geral do Processo. São Paulo: Malheiros Editores, 2001 .

COMOGLIO, Luigi Paolo. Preclusioni instruttorie e diritto alla prova. In: Rivista di Diritto Processuale, anno LIII (Seconda Serie), n 4, pp. 968-995, ottobre-dicembre 1998.

CRETELLA JÚNIOR, José. Comentários à Constituição 1988, vol. I. Rio de Janeiro: Forense Universitária, 1997.

DIDIER JÚNIOR, Fredie. Curso de direito processual civil - teoria geral do processo e processo de conhecimento. Salvador: Edições Podivm, 2006, p. 57.

DIDIER JÚNIOR, Fredie; BRAGA, Paula Sarno; OLIVEIRA, Rafael Alexandria de. Curso de direito processual civil - teoria geral da prova, direito probatório, decisão, precedente, coisa julgada e tutela provisória. Salvador: Editora JusPodivm, 2015.

DINAMARCO, Cândido Rangel. O princípio do contraditório. In: Revista da Procuradoria Geral do Estado de São Paulo, n 19, pp. 2 | -38, dezembro de | 98 | .

DORIA, Antônio Roberto. Direito constitucional tributário e o due processo of law. Rio de Janeiro: Editora Forense, 1986. 
ECHANDÍA, Hernando Devis. Teoria General de la prueba judicial, Tomo I. Buenos Aires: Victor P. de Zavalia - Editor, 1974.

FUX, Luiz. Processo e Constituição. In: FUX, Luiz(Coord.). Processo Constitucional. Rio de Janeiro: Editora Forense, 2013, pp. 3-44.

GOLDSCHMIDT, James. Direito Processual Civil, traduzido, revisado, adaptado e anotado por Ricardo Rodrigues Gama. Curitiba: 2003b.

Direito processual civil, Tomo I. Traduzido por Lisa Pary Scarpa. Campinas: Bookseller Editora e Distribuidora, 2003a.

GRINOVER, Ada Pellegrini. Novas tendências do direito processual de acordo com a Constituição de 1988. Rio de Janeiro: Forense Universitária, 1990.

. Os princípios constitucionais e o código de processo civil. São Paulo: José Bushatsky Editor, 1975.

JORGE, Nuno Lemos. Direito à prova: brevíssimo roteiro jurisprudencial. In: Julgar, n. ${ }^{\circ}$ 6, pp. 99-106, setembro/dezembro 2008.

LUCON, Paulo Henrique dos Santos. Devido processo legal substancial e efetividade do processo. In: MARTINS, Ives Gandra da Silva; JOBIM, Eduardo (Coord.). O Processo na Constituição. São Paulo: Editora Quartier Latin do Brasil, 2008.

MARQUES, José Frederico. Instituições de Direito Processual Civil, volume II. Campinas: Millenium Editora, 2000.

MENDES, Gilmar Ferreira; BRANCO, Paulo Gustavo Gonet. Curso de Direito Constitucional. São Paulo: Editora Saraiva, 2015.

MESQUITA, Gil Ferreira de. Princípios do contraditório e da ampla defesa no processo civil brasileiro. São Paulo: Editora Juarez de Oliveira, 2003.

MICHELI, Gian Antônio. Curso de derecho procesal civil, volume I, Parte General. Buenos Aires: Ediciones Juridicas Europa-América, 1970.

MIRANDA, Jorge. Direito Constitucional aditamentos. Lisboa: Faculdade de Direito da Universidade de Lisboa, 1982.

NERY JÚNIOR, Nelson. Princípios do Processo Civil na Constituição Federal. São Paulo: Editora Revista dos Tribunais, 2002.

OLIVEIRA, Carlos Alberto Álvaro de. O juiz e o princípio do contraditório. In: Revista de Processo, n 7I, pp. 31-38, julho/setembro 1992. 
. Princípios do contraditório e da ampla defesa. In: CANOTILHO, J. J. Gomes; MENDES, Gilmar Ferreira; SARLET, Ingo Wolfgang; STRECK, Lênio Luiz; LEONEY, Léo Ferreira (Coords.). Comentários à Constituição do Brasil - Série IDP. São Paulo: Editora Saraiva, 2013.

PARIZ, Ângelo Aurélio Gonçalves. O princípio do devido processo legal: direito fundamental do cidadão. Coimbra: Almedina, 2009.

PICARDI, Nicola. II principio del contraddittorio. In: Rivista di Diritto Processuale, anno LIII, n³, pp. 673-68I, luglio-settembre 1998.

PORTUGAL. Lei n. ${ }^{\circ} 4$ I/2013, de 26 jun. Código de Processo Civil. Disponível em: <http://www.pgdlisboa.pt/leis/lei_mostra_articulado.php?nid=1959\&tabela=leis $>$. Acesso em: 8 set. 2018.

- Constituição da República Portuguesa. Disponível em: <https://www. parlamento.pt/Legislacao/Documents/constpt2005.pdf>. Acesso em: 8 set. 2018.

RAMOS, Vitor de Paula. Direito fundamental à prova. In: Revista de Processo, São Paulo, n 38, vol. 224, pp. 41-62, out. 2013.

RANGEL, Rui Manuel de Freitas. O ònus da prova no processo civil. Coimbra: Edições Almedina, 2006.

RIBEIRO, Darci Guimarães. A dimensão constitucional do contraditório e seus reflexos no projeto do CPC/20 I5. In: Revista de Processo, São Paulo, n 39, vol. 232, pp. 13-35, jun. 2014.

SANTOS, Moacyr Amaral. Prova judiciária no cível e comercial. São Paulo: Max Limonad, 1970.

SILVA, José Afonso. Curso de direito constitucional positivo. São Paulo: Malheiros Editores, 2001.

Recebido em: 29/09/2018

Aprovado em: $17 / 05 / 2019$ 
JOSÉ EUSTÁQUIO DE MELO JÚNIOR GUSTAVO PASCHOAL TEIXEIRA DE CASTRO OLIVEIRA 